Journal of English Language Teaching

\title{
Representing translation procedures in translated Indonesian-English cultural terms of online news media
}

\author{
Siti Rodiyah ${ }^{\bowtie}$
}

Faculty of Teacher's Training and Education, Universitas Tama Jagakarsa

\begin{tabular}{l} 
Article Info \\
\hline Article History: \\
Received in 16 June \\
2020 \\
Approved in 29 \\
November 2020 \\
Published in 30 \\
November 2020 \\
\hline Keywords; cultural \\
terms; translation; \\
procedure; The Jakarta \\
Post
\end{tabular}

Post

\begin{abstract}
Translating cultural terms needs proper procedures since each culture has linguistics elements to be expressed between one language to other ones. Problems then may appear in understanding cultures. However, it should not be a big deal, because understanding cultures of one language to other ones can be easily resolved by translation and its proper procedures. The present study uses qualitative approach with content analysis which is aimed to observe (1) The translated Indonesian-English cultural terms on The Jakarta Post's (TJP) Online News and (2) The translation procedures using in replacing the Indonesian cultural terms into English. The 21 cultural terms of five texts in TJP were found as the data and they were analyzed based on the adaptation of Newmark's categorisation of cultural terms and a combination view of Newmark's and Baker's translation procedures. The results of this study were; First, the translated Indonesian cultural terms into English on TJP's Online News were categorized into social-religious activities cultural terms which reached the most $48 \%$, ecological cultural terms found $28 \%$, and material cultural terms obtained the lowest $24 \%$. Second, the translation procedures used in replacing Indonesian cultural terms found in this study are four types of procedures; couplets obtained the highest percentage 48\%; literal translation gained $19 \%$, transference or loan word and loan word plus explanation reached $24 \%$, and cultural equivalent or cultural substitution obtained the lowest $9 \%$. This study applied to observe Indonesian-English cultural terms and their translation procedures of online media to acknowledge Indonesian cultures through news widely.
\end{abstract}




\section{INTRODUCTION}

Human beings think and act differently toward their lives through variety of ways which called culture. Hoopes (in Pusch, 1979) states his terminology on culture that it is the sum total of ways of living which developed by a group of people. Moreover it concluded that through a particular phsyical and human environment to survive, people have their own ways about values, beliefs, aesthetic standard, and pattern of thinking, behavioral norms, linguistics expression, and style of communication. Newmark (1988) emphasizes that it is a community uses a specific language as its tool to express the way of life as their culture. Thus, every culture has its particular characteristics whether type of culture and language to express it.

The nature of culture is different from one community to others and Rodiyah (2014) noted that it is each culture has its own virtue due to its function in each group of lives. For those people who live with their own ways from generation to next generation, they do understand the importance and the historical background of their cultures which other communities can catch them through deep explanation. That it is every culture has its own linguistics forms whether stuctures or systems, so problems may appear in understanding cultures which those have own linguistics elements to express between one language to other ones. It means that cultural terms related to language issues.

Eventhough understanding cultures of a source language (SL) to a target language (TL) is challenging, the problems that appear then can be easily resolved by translation and its proper procedures. Thus, to translate should learn knowledge of culture, and vice versa, to recognize culture should learn its language. As it has been decided by Al-Hassan (2013) that the domain of translation studies has expanded beyond the limit of language to include the cultures of the SL and TL. In other words, Durdureanu (2011) states culture and translation have been integrated each other. Translation and culture are interrelated, so that translator can no longer ignore cultural elements in text.

The nature of translation is varied among linguists, scholars, and professionals in translation studies, though it generally assumed that translation included process and product. As process, translator applied any levels and categories in transferring SL into TL. While translation product provided by translator after having completed the process of translation. Catford (1965) defines translation as replacing textual material of an SL by equivalent textual material into TL. Nida and Taber (1982) naturally define that translation is a reproduction of whether the closest message meanings or terms of style from SL to TL.

Since understanding cultural items may bring problems, it has been interesting to be observed through many studies about culture and translation . As it is been studied by Hapsari \& Setyaningsih (2013) on Cultural words and the translation in Twilight; Thriveni (2016) who found cultural element in translation the Indian Perspective; Nitisari (2016) with her The Translation Strategies of Cultural Words in Ahmad Tohari's Dancer: Permatahati \& Rosyidi (2017) with their Translation Techniques and Readability of The Culture Specific Items in the 2007 Indonesian Translation of Alice's; Suhardi and Setiawan (2019) studied about equivalence of proper names which included cultural items, in foreign languages into the Indonesian language; Rodiyah's (2019) about Translation strategies of cultural terms in booklet Warisan Budaya Jakarta-Jakarta Cultural Heritage; Indryany (2019) by her Strategi Penerjemahan Kata-Kata Berkonsep Budaya dalam Novel Terjemahan The Great Gatsby. These mentioned studies observed translation and cultural terms which are based on literary works and any other objects unless using news media as the object. To accomplish those studies, so this current study observes representation of using particular translation procedures to replace Indonesian cultural terms into English of the JP's online news text which is used as both the object and the data in this study.

In relation between translation and culture, Newmark (1988) classified cultures into five categories; the first is ecology; the second is material culture; the third is social culture - work and leisure; the fourth is organisations, customs, ideas-political, social, legal, religious and artistic; the fifth is gestures and habits. Based on those categorization, the researcher then has adapted and interpreted them into three categorization as follows; the first is ecology which associated with everything related to environment. The sub-categories can be animal, plants, wind, proper names of geographical area (including name of street, sub-district, province and capital city of province), zone, mountains, land, etc. The second is material cultures which related to human creativity in optimizing God's creation to be food or culinary, clothes, houses or historical buildings, and artworks. The third is social-religious activities cultural terms which it is a combined of the third and fourth Newmark's categorization. It can be sub-categorized into religious festivals, artistic, and seasonal activities which these sub-categories are mostly manifested by Indonesian people through festivals and ceremonial to 
celebrating holydays or holy days which are the manifestation of human's thought in doing their daily activities.

To translate those categories of cultural terms, it can be applied by Newmark's procedures (1988) which it is developed into 16 procedures that possibly used by translator. Here they are four procedures which mostly applied in translating cultural words whether in single or couplet used as it is the main objective of this study: (1) Literal translation is one of the easiest used procedures in translating cultural words which it can only take equivalent meaning lexically from dictionary. This procedure used as the very first way by translator to find equivalent meaning, (2) Cultural equivalent can be used as a procedure to translate cultural word by replacing source cultural words into target cultural words which they have similarity in meaning, (3) Transference as same as borrowing that used by translator with only using the source language without any replacement, (4). Couplets used two or more procedures in one translation text.

Procedures of translation sometimes used regarding problems of non-equivalence. Professional translators will deal with various types of non-equivalence by using strategies. Baker (2011) delivered at least six procedures which can be used to be strategies in dealing with nonequivalence problems; (1) translation by a more general word (super ordinate), (2) translation by a more neutral/less expressive word, (3) translation by cultural substitution, (4) translation using a loan word or loan word plus explanation, (5) translation by paraphrase using a related word, (6) translation by paraphrase using unrelated words.

Indonesia is home to tons of cultures of many ethnics in this archipelago country. Those cultures have their own uniqueness as well as other cultures all over the world. So every culture has its own name of language to be expressed using particular words. There are many literatures provided to acknowledge Indonesian cultures; government manuscripts, textbooks, booklet of cultures or tourism, media, etc.

Thus, any media plays important roles to acknowledge cultural terms to other people worldwide. Daily news using foreign language whether paper edition or online is one of media that can provide cultural terms from one language to others. For general rules, media has also its own language to deliver information, either it has own way to translate local language to foreign ones, and vice versa.

That it is one of the media, The Jakarta Post, which it used to be only a paper based, but now it is also online English news based in Jakarta, Indonesia. That it was very first paper edition appeared on 25 April 1983. In Indonesian perspective, The Post established to improve the standard of English language media and to produce a quality newspapers to its reader in deepening their insight into the very workings of this vast archipelago, its people and its government, as members of the great family of nations (The Post, 2011). In other words, from these objectives implied that how Indonesians apply the way of life presented to the public by The Post using journalism standard, so people can understand Indonesian cultures.

The Post has important roles as well as other publication in representing Indonesian cultural terms through any kinds of news. There are many studies applied to observe translation and cultures on artworks of literature or cultural terms in any object from English into Indonesian language. While this study concerns on both issues, culture and translation, it also represents Indonesian cultural erms translated into English and the translation procedures used in replacing the Indonesian cultural terms into English on TJP's Online News.

\section{METHODS}

This study uses qualitative approach with content analysis to observe; (1) The translated Indonesian cultural terms into English on the Jakarta Post's (JP) Online News and (2) The translation procedures using in replacing the Indonesian cultural terms into English. The data were taken from five articles which consist of Indonesian cultural terms translated into English on the Jakarta Post's Online News. The five articles entitled: (1) 'Kerak telor', grilled octopus spice up Cap Go Meh in Jakarta published on Saturday, February 8, 2020, (2) From religious rituals to festive attractions: Indonesians prepare to celebrate Chinese New Year on Friday, January 24, 2020, (3) Jakarta celebrates Cap Go Meh with festival, performances on Sat, February 8, 2020, (4) Seven interactive installations to enjoy at Bandung's Gedung Sate on Sunday, January 26, 2020, (5) Toba Lake Festival fails to bring in tourists on December 16, 2019.

The data gathered by collecting the categorization of each cultural terms and classifying their translation procedures on the Jakarta Post' five texts which they were analyzed using qualitative data 
analysis. The evidence provided in tables and percentage to facilitate readers easier to sum up the research. The theoritical framework used to analyze the first problem were Newmark's definition of cultural terms which are have been adapted and interpreted by the researcher into three categorization as follows; the first is ecology which associated with everything related to environment. The sub-categories can be animal, plants, wind, proper names of geographical area (including name of street, sub-district, province and capital city of province), zone, mountains, land, etc. The second is material cultures which related to human creativity in optimizing God's creation to be food or culinary, clothes, houses or historical buildings, and artworks. The third is socialreligious activities cultural terms which it is a combined of the third and fourth Newmark's categorization. It can be sub-categorized into religious festivals, artistic, and seasonal activities which these sub-categories are mostly manifested by Indonesian people through festivals and ceremonial to celebrating holydays or holy days which are the manifestation of human's thought in doing their daily activities. And to answer and analyze the second aim of this study, it also based on Newmark's (1988) and Baker's (2011) translation procedure. The result found 21 cultural terms of some categorizations answering two formulated problems; First, the translated Indonesian cultural terms into English on the JP's Online News which were categorized into social-religious activities ecology, and material. Second, the translation procedures used in replacing Indonesian cultural terms found in this study were four types of procedures; couplets which it is using more than one procedures in translating one cultural term such a combination of cultural equivalent and transference or loan word plus explanation, couplets of transference and translation by paraphrase using a related word, and couplets of transference and literal translation. There are also single procedures that have been used; literal translation, transference and loan word or loan word plus explanation, and cultural equivalent or cultural substitution.

\section{FINDINGS AND DISCUSSION}

Based on the data analysis of 21 cultural terms, the study obtained two objects which are formulated as problems. First, the translated Indonesian cultural terms into English on the JP's Online News are categorized into social-religious activities cultural terms which reached the most $48 \%$, ecological cultural terms found $28 \%$, and material cultural terms obtained the lowest $24 \%$. Second, the translation procedures used in replacing Indonesian cultural terms found in this study are four types of procedures; couplets obtained the highest percentage $48 \%$ for 10 cultural terms which it is a using more than one procedures in one cultural term such a combination of cultural equivalent and transference or loan word plus explanation, couplets of transference and translation by paraphrase using a related word in bracket, and couplets of transference and literal translation. There are also single procedures that have been used; literal translation gained 19\% to translating five cultural terms, transference or loan word and loan word plus explanation reached $24 \%$ to retain four cultural terms, and cultural equivalent or cultural substitution obtained the lowest $9 \%$ to replace two cultural terms. Here they are the discussion of results:

\section{The Indonesian Cultural Terms in Categorizations}

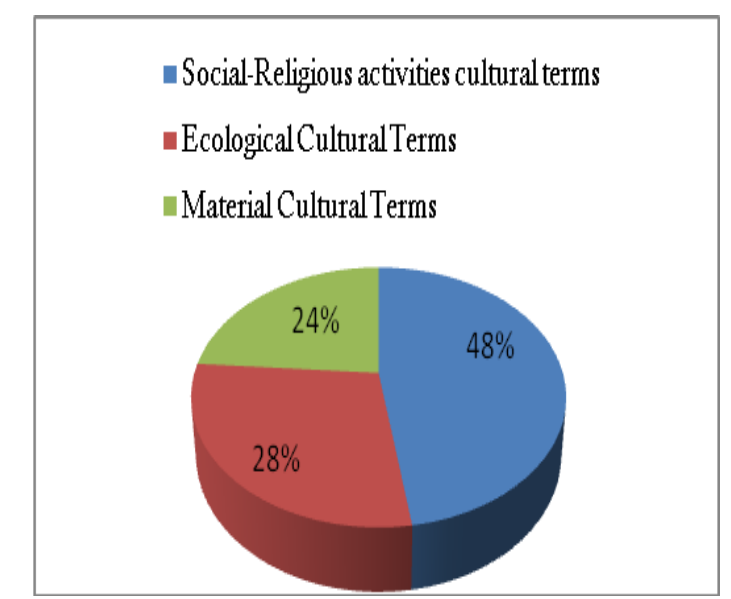

Figure 1. Categorization and total of cultural terms 
This part began with a figure above containing percentage of cultural terms in each category and then continued by description of each formulated problem. Based on the data analysis, there are 21 Indonesian cultural terms which found in five articles of the Jakarta Post News with different categories. Social-religious activities cultural terms stand for the highest percentage $48 \%$, ecology found $28 \%$, and material obtained the lowest $24 \%$. The types of articles on the news decided as travel, culture, and life styles. Here the description of cultural terms in each categorisation:

\section{Social-religious activities cultural terms}

Table 1. Social-Religious activities cultural terms

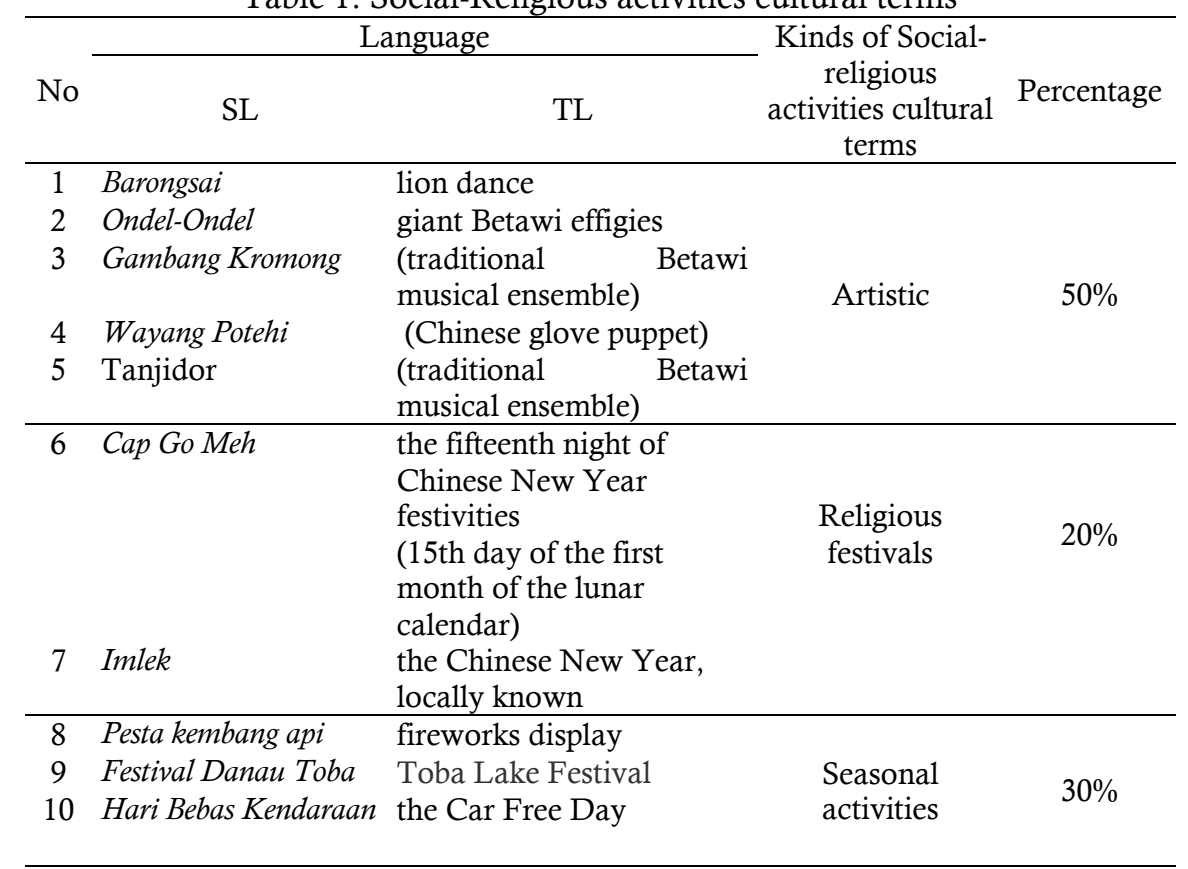

Indonesia is home to hundreds of ethnics with many different cultures. People from all over Indonesia are born from many kinds of ethnic groups. So they live in many ways of living. Through social-religious activities which are varied, they do rituals and celebration. As this study adapted theoritical framework by Newmark (1988), this study determined three sub-categorizations of this cultural terms as the results which are artistics reached $50 \%$, religious festivals stand for $20 \%$, and seasonal activities gained $30 \%$.

Festival is one of cultural products that is related to how Indonesians to do worship, to celebrate happiness of holy days, and to show people's feel and locals sources. So, it is easy for the journalist to write social-religious activities in every corner of Indonesia due to the richness of cultures of this archipelago country. Like social-religious activities cultural terms easily found in articles which are taken as the data of this study. There are 10 of 21 Indonesian translated socialreligious activities cultural terms into English in the data which taken from one of five articles entitled "Jakarta celebrates Cap Go Meh with festival performances".

After analysing the data that were taken from paragraphs consisting words and phrases, this study then found religious terms which some of them are Imlek and Cap Go Meh. These two words have close relation to an ethnic called Chinese-Indonesian people who live in Indonesia since long time ago. They have established particular cultures based on the root of culture from their descent, Chinese, which can be referred not only in Indonesia but also all over the world with different names as Chinese people live in every corner in the world. Imlek is a term among locals in Indonesia, especially chinese of mixed Indonesian descent, to replace Chinese New Year which people all over the world known it universally. According to Hermina (as cited in Kompas.com, 2020), Imlek has been celebrated through series acitivities which originally was a celebration of the beginning of spring and it by philosophers then been integrated to morality and spiritual values.

Imlek usually celebrated within 15 days which finally completed with festivites on its fifthteenth day of the month. It is Cap Go Meh which translated to the fifteenth night, a popular word 
among Indonesians as one of series religious rituals. Cap Go Meh is a part of Imlek which shown up by festive attractions. In this study, this word found as one of subcategory which it is a religious day as implied in example 6 in Table 1 above. Here the word appeared in two paragraphs from TJP's article entitled "Jakarta celebrates Cap Go Meh with festival, performances":

The Jakarta administration has organized Cap Go Meh celebrations that will last until Sunday.

Also known as the "happy day", Cap Go Meh, which translates to the fifteenth night, is what closes 15 days of Chinese New Year festivities. This year, Cap Go Meh falls on Saturday.

The festivities began Thursday and celebrations are currently being held in five areas: in front of the Grand Hyatt hotel, Dukuh Atas, the Kendal Tunnel, in front of the FX Sudirman shopping mall and the Thamrin City shopping mall.

As Newmark (1988) notes that one of cultural terms categorization is associated to organisations, customs, ideas-political, social, legal, religious and artistic, this study found the most cultural terms on this categorisation. It implied human being can not be separated of activities, especially on religious, seasonal and artistics terms in their daily activities. So, in translation as a product it also can be easily found through studies e.g. that it is a study by Hapsari and Setyaningsih (2013) found the third highest (18\%) of this categorisastion which subcategorized on terms of artistic and religion. It implied that human's ways of live can be easily identified through religious rituals and festives attracations.

\section{Ecological Cultural Terms}

Table 2: Ecological cultural terms

\begin{tabular}{lllll}
\hline \multirow{2}{*}{ No } & \multicolumn{1}{c}{ SL } & \multicolumn{1}{c}{ TL } & \multicolumn{1}{c}{$\begin{array}{l}\text { Kinds of } \\
\text { Ecological terms }\end{array}$} & Percentage \\
\cline { 2 - 4 } 1 & $\begin{array}{l}\text { Jl. Pancoran, } \\
\text { Kelurahan } \\
\text { Pinangsia, Jakarta } \\
\text { Barat }\end{array}$ & $\begin{array}{l}\text { Jl. Pancoran in Pinangsia } \\
\text { subdistrict, West Jakarta }\end{array}$ & $\begin{array}{l}\text { Street, subdistrict } \\
\text { and city }\end{array}$ & $16.7 \%$ \\
\hline 2 & $\begin{array}{l}\text { Petak Sembilan } \\
\text { Glodok }\end{array}$ & $\begin{array}{l}\text { Not translated but before } \\
\text { already described as one } \\
\text { of three Little Chinatown } \\
\text { points in the city }\end{array}$ & Zone & $16.7 \%$ \\
\hline 3 & Sumatera Utara & North Sumatra & Province & $16.7 \%$ \\
\hline 4 & $\begin{array}{l}\text { Bandung, Ibu Kota } \\
\text { Jawa Barat, }\end{array}$ & $\begin{array}{l}\text { Bandung, the capital of } \\
\text { West Java, }\end{array}$ & $\begin{array}{l}\text { Capital city of } \\
\text { province }\end{array}$ & $16.7 \%$ \\
\hline 5 & $\begin{array}{l}\text { Jakarta Timur } \\
6\end{array}$ & $\begin{array}{l}\text { East Jakarta } \\
\text { Wakarta Barat }\end{array}$ & City & $33.33 \%$ \\
\hline
\end{tabular}

Basically this study depends on Newmark's (1988) framework especially on categorization of ecological terms in translation. Through this present study then it determined additional more subcategories due to the variety of cultural terms found from the news texts such as names of street, sub-district, zone, province and capital city of province which are not literally mentioned by Newmark. It is similar to the prior research by Indriyani (2019) that she found ecological terms in her study which it were geographical terms. There are six ecological terms of 21 of Indonesian translated cultural terms as the data found in this study. This category of cultural terms appeared in form of words and phrases. Based on the sentence analysis data which consists of words and phrases, it can be seen through the following paraghraph from an article entitled "'Kerak telor', grilled octopus spice up Cap Go Meh in Jakarta":

Forty-five food stalls serving a variety of delicacies were displayed at a culinary festival on $J$. Pancoran in

Pinangsia subdistrict, West Jakarta, to celebrate Cap Go Meh on Saturday.

The two lines paragraph above consists of ecological terms such as Jl. Pancoran in Pinangsia subdistrict, West Jakarta. To locals in Jakarta or Indonesia at general, it is common to write or mention their own address completely which included name of street with name of subdistrict (kelurahan) and city (kotamadya). As product of cultures, those ecological terms cannot be fully replaced by other words in foreign language unless using additional information like $\mathrm{Jl}$. means street before Pancoran, subdistrict after Pinangsia and end up by name of city West Jakarta. 


\section{Material Cultural Terms}

Table 3. Material Cultural Terms

\begin{tabular}{|c|c|c|c|c|}
\hline \multirow{2}{*}{ No } & \multicolumn{2}{|c|}{ Language } & \multirow{2}{*}{$\begin{array}{c}\text { Kinds of } \\
\text { Material Terms }\end{array}$} & \multirow{2}{*}{ Percentage } \\
\hline & SL & TL & & \\
\hline 1 & Kerak telor & $\begin{array}{l}\text { Grilled octopus, } \\
\text { Betawi-style omelet made } \\
\text { of duck eggs and rice }\end{array}$ & Fond & \\
\hline 2 & Dodol Betawi & $\begin{array}{l}\text { a traditional toffee-like } \\
\text { sweets made of palm } \\
\text { sugar }\end{array}$ & Food & $40 \%$ \\
\hline 3 & Taman Dukuh Atas & the Dukuh Atas Park & Public place & $20 \%$ \\
\hline 4 & $\begin{array}{ll}\text { Vihara } & \text { Gunung } \\
\text { Timur } & \\
\end{array}$ & Gunung Timur Temple & $\begin{array}{c}\text { Religious } \\
\text { building }\end{array}$ & $20 \%$ \\
\hline 5 & Gedung Sate & $\begin{array}{l}\text { Gedung Sate, a Dutch } \\
\text { East Indies heritage } \\
\text { building built in } 1920 .\end{array}$ & $\begin{array}{l}\text { Historical } \\
\text { building }\end{array}$ & $20 \%$ \\
\hline
\end{tabular}

Material cultural terms found the lowest in this study which it is $24 \%$. There are 5 of 21 Indonesian translated cultural terms into English in the data which taken from five articles of The Post's online News. Material cultural terms appeared in form of words and phrases as listed in Table 3 above. The sub-categories of this term are food, historical buildings, religious buildings, and public place. It considered that material cultural terms also important among Indonesian, even in some studies it found the most.

Based on the sentences analysis data which consist of words and phrases, this study found five material terms in five articles. Food is one of some sub-categories as implied in example 1 and 2. Here it is the sentence:

"The culinary festival will last during the weekend, offering food and beverages ranging from traditional favorites of Jakarta's Betawi people, such as kerak telor (Betawi-style omelet made of duck eggs and rice) and dodol betawi (a traditional toffee-like sweets made of palm sugar) to Chinese staples like dumplings and fried meatballs."

Kerak telor is one of popular local foods among Jakarta's Betawi people. It can be literally translated as egg crust. It called Betawi omellet but little bit different from common omellet. As common omellet, Kerak telor also made of egg, chicken or duck, and many spices. This food to be crust because of it consisted of sticky rice which cooked until fried looked. Serundeng (roasted shredded coconut), fried shallots and fried shrimp put as toping. Dodol Betawi which recognized in the bracket as a traditional toffee-like sweets made of palm sugar is also very popular among locals in Jakarta. Sweet dominated the taste of Dodol Betawi. It is rubbery like marshmallow but the ingredients so much different which it puts palm sugar and milk squeezed from coconut.

Many studies obtained material as one of cultural terms categorisation. Rodiyah (2019) found similar subcategory to the current study which highlighted on historical buildings, clothes, and transportations. This study found one more thing related to material culture which it is religious building Vihara Gunung Timur or Gunung Timur Temple. That it is a subcategory can be easily found around Indonesian's environment, religious buildings, as Indonesia is a country that have six religions; Islam, Protestantism, Catholicism, Hinduism, Buddhism, and Confucianism. So, people in Indonesia are allowed and facilitated to do worship in religious buildings which are opened publicly such as mosques, temples, and churchs. 


\section{Translation Procedures}

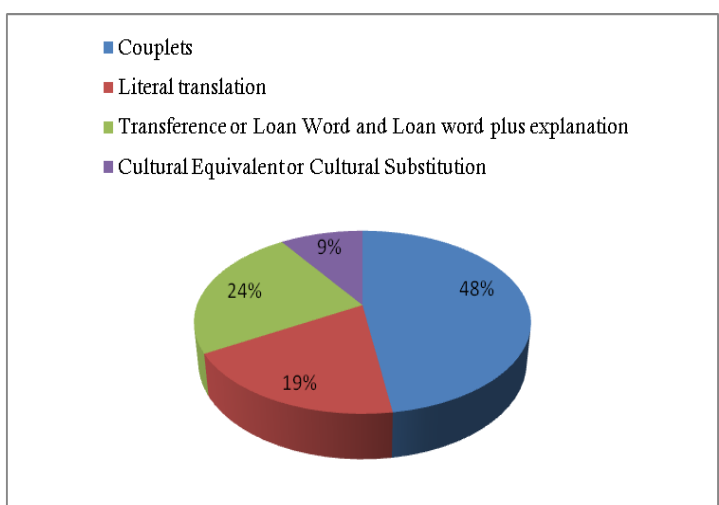

Figure 2. Translation Procedures

This part describes the translation procedures used in translating the 21 Indonesian cultural terms found in this study based on the data analysis of five articles of the Jakarta Post News. There are four types of procedures used due to the way how journalists replace the 21 Indonesian cultural terms into English.

The four procedures are: (1) couplets obtained 48\% which it is a using more than one procedures in one cultural term such a combination of cultural equivalent and transference or loan word plus explanation, couplets of transference and translation by paraphrase using a related word in bracket, and couplets of transference and literal translation. There are also single procedures that have been used such as (2) literal translation gained 19\%, (3) Transference or loan word reached and loan word plus explanation 24\%, and (4) Cultural Equivalent or Cultural Substition obtained the lowest $9 \%$.

\section{Couplets}

Table 4. Couplet Procedure

\begin{tabular}{|c|c|c|c|}
\hline \multirow{2}{*}{ No } & \multicolumn{2}{|c|}{ Language } & \multirow{2}{*}{ Translation Procedures } \\
\hline & SL & TL & \\
\hline 1 & Kerak telor & $\begin{array}{l}\text { Grilled octopus, } \\
\text { Betawi-style omelet } \\
\text { made of duck eggs and } \\
\text { rice }\end{array}$ & $\begin{array}{l}\text { Couplets: Cultural } \\
\text { Equivalent, Transference or } \\
\text { loan word plus explanation }\end{array}$ \\
\hline 2 & Barongsai & (lion dance) & $\begin{array}{l}\text { Couplet: transference and } \\
\text { translation by paraphrase } \\
\text { using a related word }\end{array}$ \\
\hline 3 & Ondel-Ondel & (giant Betawi effigies) & $\begin{array}{l}\text { Couplet: transference and } \\
\text { translation by paraphrase } \\
\text { using a related word in } \\
\text { bracket }\end{array}$ \\
\hline 4 & Tanjidor & $\begin{array}{l}\text { (traditional Betawi } \\
\text { musical ensemble) }\end{array}$ & $\begin{array}{l}\text { Couplet: transference and } \\
\text { translation by paraphrase } \\
\text { using a related word in } \\
\text { bracket }\end{array}$ \\
\hline 5 & Wayang Potehi & (Chinese glove puppet) & $\begin{array}{l}\text { Couplet: transference and } \\
\text { translation by paraphrase } \\
\text { using a related word in } \\
\text { bracket }\end{array}$ \\
\hline 6 & Taman Dukuh Atas & the Dukuh Atas Park & $\begin{array}{l}\text { Couplet: Transference and } \\
\text { Literal translation }\end{array}$ \\
\hline 7 & Festival Danau Toba & Toba Lake Festival & $\begin{array}{l}\text { Couplet: transference and } \\
\text { literal translation }\end{array}$ \\
\hline 8 & Vihara Gunung Timur & $\begin{array}{l}\text { Gunung Timur Temple } \\
\text { Vihara Gunung Timur } \\
\text { Temple }\end{array}$ & $\begin{array}{l}\text { Couplet: Transference and } \\
\text { Literal translation }\end{array}$ \\
\hline
\end{tabular}


9 Jl. Pancoran, Kelurahan Pinangsia, Jakarta Barat

10 Dodol Betawi

\begin{tabular}{ll} 
Jl. Pancoran in & Couplet: Transference and \\
Pinangsia subdistrict, & Literal translation \\
West Jakarta & \\
$\begin{array}{c}\text { a traditional toffee-like } \\
\text { sweets made of palm } \\
\text { sugar }\end{array}$ & $\begin{array}{c}\text { Couplet: transference or word } \\
\text { plus explanation and cultural } \\
\text { equivalent }\end{array}$ \\
\hline
\end{tabular}

In process of translating cultural terms, translators should adopt different procedures. It commonly recognized that it is not easy to keep source language (SL) into target language (TL) which is functionally equivalent. It sometimes can not be solved by only one procedure for translating a cultural term. This is a such problem when translator need to use and to apply couplet, one of procedures addressed by translation scholars. Nasser (2018) emphasizes to solve a problem in one translation unit need to apply couplet which is a use of two procedures or more.

Translation couplets. The most common form of translation couplet consists of the translation of an institutional term followed by its translation (which may be a literal translation, a cultural equivalent or a translation label) in brackets; here one would assume that the SL term would be retained for the remainder of the text and in the relevant TL literature. (Newmark, 1981, p. 76).

The statement above implied that couplet which uses more than one procedure is not only provided for resolving problem but also it is such an effort of translator to retain both SL and TL terms culturally equivalent. Providing meaning of a cultural term in brackets from SL to TL or vice versa combining with other procedures is such a way of applying couplet.

This study found that couplet as a procedure used to translate ten cultural terms of some subcategories. It applied into a combination of cultural equivalent and transference or loan word plus explanation, couplets of transference and translation by paraphrase using a related word, and couplets of transference and literal translation. Most of them replaced in brackets. The following paragraph consists a material cultural word "ondel-ondel" which translated by couplet.

Visitor can expect to enjoy various forms of art and performances at the celebrations, including ondel-

ondel (giant Betawi effigies), wushu, Chinese lute and film screenings.

Ondel-ondel written with additional information in bracket after the word ondel-ondel itslef, so it called using couplet procedure because it is translated by paraphrase using a related word in bracket to giant Betawi effigies. This paraphrase related to its big shape of ondel-ondel, so it looks like a giant doll. It sure the word ondel-ondel cannot be replaced by any other word in English unless the journalist paraphrase it using related words.

\section{Literal Translation}

Table 5. Literal translation

\begin{tabular}{clll}
\hline $\mathrm{N}$ & \multicolumn{2}{c}{ Language } & \multirow{2}{*}{ Translation Procedures } \\
\cline { 2 - 3 } $\mathrm{o}$ & \multicolumn{1}{c}{ SL } & \multicolumn{1}{c}{ TL } & Literal translation \\
\hline 1 & Jakarta Timur & East Jakarta & Literal translation \\
2 & Jakarta Barat & West Jakarta & Literal translation \\
3 & Sumatera Utara & North Sumatra & Literal translation \\
4 & Bandung, Ibu & Bandung, the capital & \\
& Kota Jawa Barat & of West Java & \\
\hline
\end{tabular}

Anderson (as cited in Suhardi et.al, 2019) explained proper names not only focused on name of person, but also included names of city and country, planet, and institution. This study found at least four ecological cultural terms as listed in Table 5. Those cultural terms are similar to what Suhardi et.al decided as a part of proper names such as Suez Canal to be Terusan Suez and South Korea to be Korea Selatan. Those both geographic proper names are reformed through general words that found lexically from TL dictionaries. In other word, this such case used literal translation procedure.

At the very first process of translation, literal translation procedure mostly used by translator. This procedure relies on general words which are easily can be found lexically in dictionary. In this way translator does not need to replace the source word into any other word but they replace word literally. As this study implied in this following sentences from TJP's article entitled "Seven interactive installations to enjoy at Bandung": 
Bandung, the capital of West Java, is home to delicious food, cafes, recreational places and tea plantations. 5

But that's not all.

Located on Jl. Diponegoro is Gedung Sate, a Dutch East Indies heritage building built in 1920.

Bandung categorized as a cultural term which is in subcategory of ecology. There is no other official name can be used to replace word Bandung as a city as well as a sub-district and even a capital city into English terms or any other languages. It is constantly written Bandung as a capital city of West Java which replacing literally Jawa Barat. So it can be implied that it used literal translation procedure.

\section{Transference or loan word and loan word plus explanation}

Table 6: Transference or loan word and loan word plus explanation

\begin{tabular}{|c|c|c|c|}
\hline \multirow{2}{*}{ No } & \multicolumn{2}{|c|}{ Language } & \multirow{2}{*}{ Translation Procedures } \\
\hline & SL & TL & \\
\hline 1 & $\begin{array}{l}\text { Petak Sembilan } \\
\text { Glodok }\end{array}$ & $\begin{array}{c}\text { Not translated but } \\
\text { before already described } \\
\text { as one of three Little } \\
\text { Chinatown points in the } \\
\text { city }\end{array}$ & Transference or Loan word \\
\hline 2 & Gambang Kromong & $\begin{array}{l}\text { It is a traditional music } \\
\text { of Betawi's people } \\
\text { which is not translated } \\
\text { in the text. }\end{array}$ & Transference or Loan word \\
\hline 3 & Gedung Sate & $\begin{array}{l}\text { Gedung Sate, a Dutch } \\
\text { East Indies heritage } \\
\text { building built in } 1920 .\end{array}$ & Loan word plus explanation \\
\hline 4 & Cap Go Meh & $\begin{array}{l}\text { (15th day of the first } \\
\text { month of the lunar } \\
\text { calendar) }\end{array}$ & Loan word plus explanation \\
\hline 5 & Imlek & $\begin{array}{l}\text { Not translated but the } \\
\text { meaning can be } \\
\text { understood through } \\
\text { reading the textin whole }\end{array}$ & Transference or loan word \\
\hline
\end{tabular}

Transference procedure by Newmark (1988) and loan word or loan word plus explanation by Baker (1992) almost the most procedures applied by the journalist of The Jakarta Post especially in translating the choosen cultural words in this study which are used five times. The five articles consist of those four cultural words that are three of them written in source term using Indonesian language which are called transference procedures and two more using loan words plus explanation in Indonesian with some words in English to get similar understanding of cultural terms meaning. Sometimes translators or, in this context is journalist, use this both way of translation to acknowledge any specific words of community to be close to the audiences or readers and with more explanation. As it implied in lines of sentences below:

For the peak of the Chinese New Year celebration, the Jakarta administration will also provide attractions to celebrate Cap Go Meh (15th day of the first month of the lunar calendar) at three Little Chinatown points in the city; Petak Sembilan Glodok in West Jakarta, Jatinegara in East Jakarta and Kampung Duri in West Jakarta.

Petak Sembilan Glodok is an area in Jakarta which is categorized as material cultural in this study and it uses transference procedure provided in the text. This procedure used to invite the readers to local place closely, eventhough the writer still can explain the place clearer with some words followed in English.

\section{Cultural Equivalent or Cultural Substitution}


Table 7: Cultural Equivalent or Cultural Substitution

\begin{tabular}{llcc}
\hline \multirow{2}{*}{ No } & \multicolumn{2}{c}{ Language } & \multirow{2}{*}{ Translation Procedures } \\
\cline { 2 - 4 } & \multicolumn{1}{c}{ SL } & TL & Cultural Equivalent or \\
& Pesta kembang api & fireworks display & Cultural Substitution \\
& & & Cultural Equivalent or \\
& Hari Bebas & the Car Free Day & Cultural Substitution \\
\hline
\end{tabular}

A language with its own uniqueness is an arbitrary tool for communication which it decided and used by a community in daily or certain activties.

A language with its own uniqueness is an arbitrary tool for communication which it decided and used by a community in daily or certain activities. However, many words of any languages have universal meaning. Cultural words are mostly unique but some of them are universal. Indonesians people have some similar activities with other civilization all over he world which are expressed with different words in different languages but have similar meaning. Newmark (1988) and Baker (1992) offer their strategies to retain this such kind of terms using cultural equivalent or cultural substition procedure. The following sentence consists of cultural word formed of a phrase that has universal meaning. The word is equivalently sustituted from Indonesian into universal cultural terms.

He said the peak of new year celebrations at the temple would fall on Tuesday, however, they would not roll out any festive performances, such as the traditional barongsai (lion dance) performance or fireworks display.

Indonesians people celebrate some events by fireworks display which it is called as pertunjukan atau pesta kembang api in Indonesian language. The words fireworks display and pertunjukan or pesta kembang api referred to particular culture which has similar activities. Thus, in the context of the above sentence, it is directly used fireworks display as it is popular among people all over the world.

\section{CONCLUSION}

Based on the data analysis, there are 21 Indonesian cultural terms which found in five articles of the Jakarta Post news with different categories. Types of article on the news decided as travel, culture, and lifestyles. Social-religious activities cultural terms mostly found in this study which there are 10 of 21 or $48 \%$ appeared in form of words and phrases representing how Indonesians do worship and celebrate happiness of holy days as well as festivals which are also the places to show people's feel and local's sources. Ecological terms found six times in the articles based for this study with some subcategories which they are street, sub-district, zone, province and capital city of province. Material cultural terms found the lowest in this study which it is $24 \%$. There are 5 of 21 Indonesian translated cultural terms into English in the data which taken from five articles of The Post's online News. There are four types of procedures used due to the way how journalists replace the 21 Indonesian cultural terms into English. The four procedures are: (1) couplets which it is a using more than one procedures in one cultural term such a combination of cultural equivalent and transference or loan word plus explanation, couplets of transference and translation by paraphrase using a related word, and couplets of transference and literal translation. There are also single procedures that have been used such as (2) literal translation, (3) transference or loan word and loan word plus explanation, and (4) cultural equivalent or cultural substitution.

English online news media that based in Indonesia take important roles to acknowledge cultures of this archipelago country worldwide. The journalists are the front liners to take roles in which they have to recognize Indonesian cultures as well as they have to translate those cultures into English through any proper procedures. Thus, Indonesian cultures will be largely known by other people whether they are using English as native speakers or as second language in good understanding as they feel so close to the Indonesian particular cultures which have been replaced naturally or universally.

\section{REFERENCES}

Al-Hassan, A. (2013). The importance of culture in translation: Should culture be translated? International Journal of Applied Linguistics and English Literature, 2 (2), 96-100. doi:10.7575/aiac.ijalel.v.2n.2p.96 
Baker, Mona. (1992). In Other Words: A Course Book of Translation. London and New York: Routledge.

Catford, J. C. (1965). A Linguistic Theory of Translation: A Essay in Applied Linguistics. Oxford: Oxford University Press.

Durdureanu, I. I. (2011). Translation of cultural terms: Possible or Impossible? The Journal of Linguistic and Intercultural Education - JoLIE, 4 (4), 52-62. DOI: https://doi.org/10.29302/jolie.2011.4.4

Gunawan, Apriadi., \& Syakriah, Ardilah. (2020, January 24). From religious rituals to festive attractions: Indonesians prepare to celebrate Chinese New Year. The Jakarta Post. Retrieved from https://www.theiakartapost.com/news/2020/01/24/from-religious-rituals-to-festiveattractions-indonesians-prepare-to-celebrate-chinese-new-year.html

Gunawan, Apriadi. (2019, December 16). Toba Lake Festival fails to bring in tourists. The Jakarta Post. Retrieved from https://www.thejakartapost.com/travel/2019/12/16/toba-lake-festivalfails-to-bring-in-tourists.html

News Desk. (2020, February 8). 'Kerak telor', grilled octopus spice up Cap Go Meh in Jakarta. The Jakarta Post. Retrieved from https://www.thejakartapost.com/news/2020/02/08/kerak-telorgrilled-octopus-spice-up-cap-go-meh-in-jakarta.html

News Desk. (2020, February 8). Jakarta celebrates Cap Go Meh with festival, performances. The Jakarta Post. Retrieved from http://www.thejakartapost.com/travel/2020/02/08/jakartacelebrates-cap-go-meh-with-festival-performances.html

News Desk. (2020, January 26). Seven interactive installations to enjoy at Bandung's Gedung Sate. The Jakarta Post. Retrieved from https://www.thejakartapost.com/travel/2020/01/26/seveninteractive-installations-to-enioy-at-bandungs-gedung-sate.html

Hapsari, Nurul Dian \& Setyaningsing, Retno Wulandari. (2013). Cultural words and the translation in Twilight. Anglicist, 02(02), 75-81.

Hoopes, Davis. (1979). Intercultural communication concepts and psychology of intercultural experience. In M. Pusch (Ed.), Multicultural Education: A cross-cultural training approach. LaGrange Park, IL: Intercultural Network.

Indryany, Fajar Nur. (2019). Strategi Penerjemahan Kata-Kata Berkonsep Budaya dalam Novel Terjemahan The Great Gatsby. Seminar Internasional Kebahasaan. Jakarta: Kemendikbud. In Sukma et.al., (Eds). Seminar Internasional Kebahasaan Kemendikbud (pp. 497-505). Jakarta, Indonesia.

Nida, Eugene A., \& Charles,j Taber. (2013). The Theory and Practice of Translation. Boston: E.J. Brill.

Newmark, Peter. (1982). Approaches to Translation: A Guide to Cross-Language Equivalence. London: Permagon Press Ltd.

Newmark, P. (1988). A Textbook of Translation. UK: Prentice Hal International.

Nitisari, Dwi. (2016). The Translation Strategies of Cultural Words in Ahmad Tohari's Dancer. UG Journal.

Permatahati, M. I., \& Rosyidi, M. I. (2017). Translation Techniques and Readability of the Culture Specific Items in 2007 Indonesian Translation of Alice's Adventures In Wonderland. ELT Forum Journal of English Language Teaching, 6(2), 116-121.

Rodiyah, Siti. (2014). Penerjemahan Istilah-Istilah Budaya dari Bahasa Inggris ke Dalam Bahasa Indonesia (Penelitian Analisis Isi Terjemahan Novel A Thousand Splendid Suns Karya Khaled Hosseini Dialihbahasakan oleh Berliani M. Nugrahani)”. (Unpublished Mater's Thesis). Pascasarjana UNJ, Jakarta, Indonesia.

Rodiyah, Siti. (2019). Strategi Penerjemahan Istilah Budaya dalam Buklet "Warisan Budaya JakartaJakarta Cultural Heritage". In Sukma et.al., (Eds). Seminar Internasional Kebahasaan Kemendikbud (pp. 430-440). Jakarta, Indonesia.

Suhardi, Widodo, Partomo., \& Setiawan, Teguh. (2019). Equivalence of proper names in foreign languages in the Indonesian language. Litera, 18 (1), 1-16. https://doi.org/10.21831/1tr.v18i1.23105

Thriveni, C. (2016). Cultural element in translation the Indian perspective. Retrieved from https: / / translationjournal.net/journal/19culture.htm.

The Jakarta Post. (2011). The Jakarta Post History. Retrieved from http://www.thejakartapost.com/about/thejakartapost history 